\title{
Strategic Planning Madrasah Pembangunan Ciputat
}

\author{
Dian Nuraini, Suryadi, Siti Zulaikha \\ Postgraduate Education Management, Jakarta State University, Jakarta, Indonesia \\ nuraini.dian@gmail.com
}

\begin{tabular}{ll}
\hline Article History: & Received: June $12^{\text {th }}$, 2020 \\
& Revised: August $13^{\text {th, } 2020}$ \\
& Accepted: September $30^{\text {th, } 2020}$ \\
\end{tabular}

\begin{abstract}
This study aims to obtain a complete picture of strategic planning in Madrasah Pembangunan. How can the organization's mandate, vision, and mission be outlined in strategic planning as a reference and guide in carrying out programs and activities? The research instrument is that a researcher is known as a human instrument-determination of informants by purposive sampling. The technique of collecting data is direct observation, photographing the research site, recording interviews with resource persons, and collecting data or documents obtained from resource persons. Findings from the research (1) Strategic planning has been implemented properly and has become a quality assurance system outlined in the quality policy and quality objectives in each unit in the Madrasah Pembangunan as a reference for every policy management. The 2018 Madrasah Pembangunan Blueprint is a planning document with a vision that is in line with current trends and can be applied to accommodate developments in the world of education that lead to technological advances and global information flows.
\end{abstract}

Keywords: Planning, Strategic, Madrasah

\section{INTRODUCTION}

Schools and madrasahs as educational institutions in the short- and longterm management require careful planning so that school management becomes effective and efficient. It can provide an overview of the steps required, alternative solutions to problems, priority matters, and the required budget with good planning. Nowadays, almost all private schools already have a strategic plan as a roadmap for their management, especially for the excellent private schools. On the other hand, with private madrasas, as providers of Islamic religious education, which are managed independently, very few make strategic planning. One Madrasah that has strategic planning is the Madrasah Pembangunan, located in Ciputat, South Tangerang.

The success of Madrasah Pembangunan in achieving achievements at the city to international level changes the perception that madrasas are only a last resort, even becoming schools that are very attractive to parents who want to educate their children with formal or religious education. Based on this, the 
researcher intends to research (1) important components contained in strategic planning, (2) strategic planning stages (3) the role of strategic planning in activities (4) constraints faced in implementing strategic planning in Madrasah Pembangunan. The focus of the problem in this research is strategic planning at Madrasah Pembangunan Ciputat. Meanwhile, the problem sub-focus is the implementation stages of strategic planning in Madrasah Pembangunan Ciputat. The results of this research are expected to be useful for the Madrasah Pembangunan UIN Ciputat and provide input and improvements regarding future strategic planning.

According to Maleka S. (2014): Strategic planning is one of the most important responsibilities of an organization's senior management. Strategic planning is one of the most important responsibilities of the senior management of an organization. Strategic planning described by Olsen and Eadie (1982) is: "I define strategic planning as a disciplined effort to produce fundamental decisions and actions that shape and guide what organization (or other entity) is, what it does, and why it does it. ". Olsen and Eadie define strategic planning as a disciplined effort to make important decisions and actions that shape and guide how to become an organization (or any other entity), what the organization (or other entity) does, and why the organization (or other entities) does such things. This makes strategic planning a management decision that outlines the design and guidelines for the organization's steps to achieve its goals according to the organization's vision and mission.

In strategic planning, the organization's vision and mission are clearly described, the organization's direction and goals, the stages of implementation, the period of achievement, performance, and tasks, up to the final result to be achieved. As edited by Dr. Burhan, N (1994) from the book Strategic Planning by George A. Steiner, strategic planning is a formal systematic effort from a company, to outline the main form of the company, its goals, policies, and strategies, to achieve goals and the main form of the company concerned. The strategic planning process is complex and participatory planning that takes the organization into unfamiliar territory, there is no standard recipe that can be applied immediately.

Allison, M. and Kaye, J. (2015) define a systematic strategic planning process approved by the organization and fosters commitment from core stakeholders to prioritize the main thing in its mission and be responsive to the organizational environment. Strategic planning directs the acquisition and allocation of resources to achieve priorities. Here's Bryson's "The ABC's of Strategic planning": 


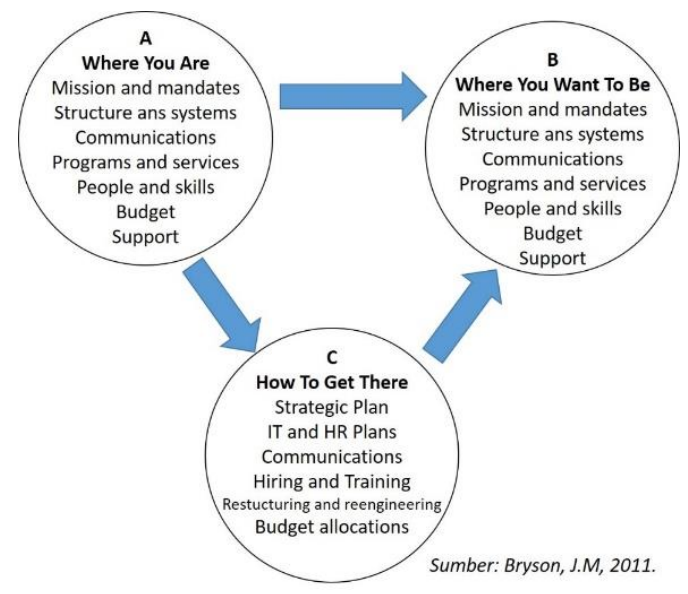

Fig. 1. ABC's Bryson

Current school management strategic planning summarizes school staff's activities and school improvement planning is the only legitimate approach for schools to prepare for its future. Therefore, for school improvement, good planning should predict all the possibilities that can occur in the future and make plans for steps to face all possibilities, both opportunities, and challenges in the future. It takes a lot of information and analysis that considers all internal and external aspects of strategic planning decisions.

According to Schlebusch and Mokhatle (2016): The purpose of strategic planning in schools is to ensure that schools can face environmental change (both internal and external). The opportunities and challenges of environmental characteristics with increasing competition require schools to successfully place themselves building on the advantages of continued competition. With strategic planning, schools must set high goals and be very focused on implementing the plan.

In general, strategic planning can be synthesized as an effort to decide options for the organization to take advantage of opportunities and face challenges faced in the future in the process of achieving organizational goals by utilizing its resources and advantages.

The hallmark of madrasas is not just the presentation of religious subjects. Islam. In the madrasa institution, what is more important is the manifestation of Islamic values in madrasa life's totality. The atmosphere of the madrasah institution that gave birth to these characteristics contains the following elements: (1) The embodiment of Islamic values in the whole life of the madrasah institution; (2) Actualized moral life, and (3) Management that is professional, open, and plays an active role in society (Tilaar, 2000). 


\section{METHOD}

According to Sukmadinata N. S (2011), qualitative research is a study that aims to describe and analyze phenomena, events, social activities, attitudes, beliefs, perceptions, thoughts of people individually, or in groups. This research was conducted for almost six months, from March 23 to July 22, 2020, at the Madrasah Pembangunan UIN JAKARTA Syarif Hidayatullah Complex, Jl. Ibnu Taimia IV South Tangerang, Banten 15419 Indonesia. The research instrument in this research is the researcher who is also known as the human instrument. Determination of informants in this study is by purposive sampling, the next informant will only be known after the previous phase of research is completed and has a snowball character where after obtaining sufficient information from the data source, the researcher will determine the next data source based on the previous data source. Data collection techniques make a direct observation, take pictures of the research site, record interviews with resource persons, and collect data or documents obtained from resource persons. Data analysis techniques are carried out from the beginning of the grand tour to the completion of the research by making notes of findings, making chronologies, compiling data, studying data, verifying data, and translating data so that they can produce theories. According to Miles and Hubenrman in Sugiyono (2015) qualitative data analysis is carried out interactively through a process of data reduction, data display, and verification.

According to Sukmadinata (2011, pp. 114-115) in general, the steps for collecting and analyzing data have similarities between one study and another, (1) Planning which formulates and delimits problems and formulates research questions directed at data collection activities. (2) Starting data collection, the researcher begins the interview with several selected informants and then continues with the member check technique. Data collection through interviews is equipped with observational data and document data (triangulation) (3) Basic data collection (4) Closing data collection (5) Complementary. The data validity test was conducted to test the data's validity, namely: credibility, transferability, dependability, and confirmability.

\section{RESULTS AND DISCUSSION}

The stages taken in preparing the 2018 Madrasah Pembangunan blueprint are as follows: (a) Formation of a blueprint drafting team selected based on its competence. This team consists of management, teachers, and committees; (b) Madrasah Self Evaluation (EDM) and evaluation of old strategic planning; (c) Brainstorming to gather ideas, ideas, common intentions, and perceptions; (d) Developing a framework for the content of the blueprint; Distribution of tasks and determining the deadline for completion; (f) Collecting tasks for the preparation of 
blueprint parts; (g) Blueprint assembly and editing; (i) Public test of the blueprint concept.

The blueprint preparation stages from the start of team formation to the concept test took approximately four months. The team formation is divided based on competence according to the components in the eight SNPs. Each team collected data and materials according to the eight SNPs which were then merged and rearranged so that they were shaped like the current blueprint.

In preparing this blueprint, there are several obstacles faced, especially because each person in the team has the main task that also requires time and a large commitment. It is quite difficult to combine time and opportunity for the team because they have to share with other obligations. Besides, the process of changing leaders in foundations and management has also resulted in the blueprint not being officially legalized as a new planning document.

The 2018 Madrasah Pembangunan Blueprint that has been prepared has not yet been ratified but has been applied as a reference for policies. The 2018 Madrasah Pembangunan Blueprint consists of 10 chapters as follows:

\section{Introduction}

In the introductory chapter, there are problems faced by the world of education as the background for making new strategic planning, apart from the fact that the old strategic planning is deemed insufficient to overcome the problems faced and accommodate existing needs so that new planning is needed to preparing Madrasah Pembangunan for the era of the industrial revolution 4.0.

In connection with the 4.0 industrial revolution era's preparation, another problem facing the world today is the Covid-19 pandemic. The absence of an effective drug and vaccine for this virus forces everyone to stay at home and maximize doing everything without contact with other people. Including schools that are currently implementing online teaching and learning activities.

\section{Vision, Mission, Goals, and Targets of the Syarif Hidayatullah State Islamic} University Development School's Development.

In this second chapter, there is the background to the establishment of Madrasah Pembangunan and its development and challenges faced, as a basis for determining the vision, mission, goals, and objectives.

\section{Graduate Competency Standards (SKL), Profiles, Curriculum, and Learning Process.}

In this chapter, there is an explanation of the character and literacy needed in education to face the 21st century. Based on these needs, the Graduate Competency Standards (SKL), student profiles, curriculum, and learning processes that can support the realization of SKL are determined.

\section{Educators and Education Personnel at Madrasah Pembangunan UIN Jakarta}


This chapter describes educators' profiles and education personnel owned by Madrasah Pembangunan from their educational background, roles, and competencies. It also describes the qualifications required as educators and education personnel at the Madrasah Pembangunan and training and the reward system for the achievements of educators and education personnel.

\section{Blueprint for Madrasah Pembangunan Facilities at UIN Jakarta}

In chapter five, a general description of the system related to the facilities and infrastructure that has been implemented is provided, details of the facilities and infrastructure owned, and the needs that need to be met. This chapter also includes problems faced by facilities and infrastructure.

\section{Management and Work Culture of MP UIN Jakarta}

This chapter discusses the concept of work culture, the factors that influence it, the conditions of the work culture in the Madrasah Pembangunan, and the work culture that will be applied in the Madrasah Pembangunan.

\section{Madrasah Pembangunan identity}

In chapter seven, the criteria for excellence and identity expected of Madrasah Pembangunan students are described.

\section{Environment and Cooperation}

Chapter eight explains the location and environment of the Madrasah Pembangunan, the school standards are healthy, child-friendly, and fun, as well as the pattern of cooperation between Madrasah Pembangunan and other institutions under applicable regulations.

\section{Evaluation}

This chapter agrees that evaluation is important and must be carried out by Madrasah Pembangunan. The form of the evaluation carried out at Madrasah Pembangunan follows eight National Education Standards as outlined in Madrasah Self-Evaluation (EDM).

\section{Closing}

Chapter 10 is a summary of the key points from the entire content of the 2018 Madrasah Pembangunan Blueprint and describes the position of Madrasah Pembangunan in education.

The 2018 Madrasah Development Blueprint has clear directions and goals. It is reflected in the stated vision, mission, goals, and objectives. It is very appropriate that education must cover the need for technology and global access to information. Technology is also very much needed to simplify and expand reach. In line with the contents of the 2018 Madrasah Pembangunan Blueprint, the current conditions of the Covid-19 pandemic are forcing every layer to adapt to the extreme, including the world of education. Restrictions and maintaining distance to everyone to reduce the risk of covid-19, stop all educational activities carried out in schools. Even so, educational activities must continue in various ways. 
All teachers and students carry out educational activities from home to carry out all learning activities without physical contact. This is about moving the location of learning and changing the curriculum and its delivery methods. To accommodate the current pandemic's educational needs, which is largely dependent on technology and the internet, a more suitable education system is needed.

\section{Implementation Stages}

Along with its development, the policymakers decided to make plans according to their needs, so that in 2018, a new strategic plan was prepared and named the 2018 Madrasah Pembangunan Blueprint.

The implementation stages of strategic planning in Madrasah Pembangunan can be described as follows:

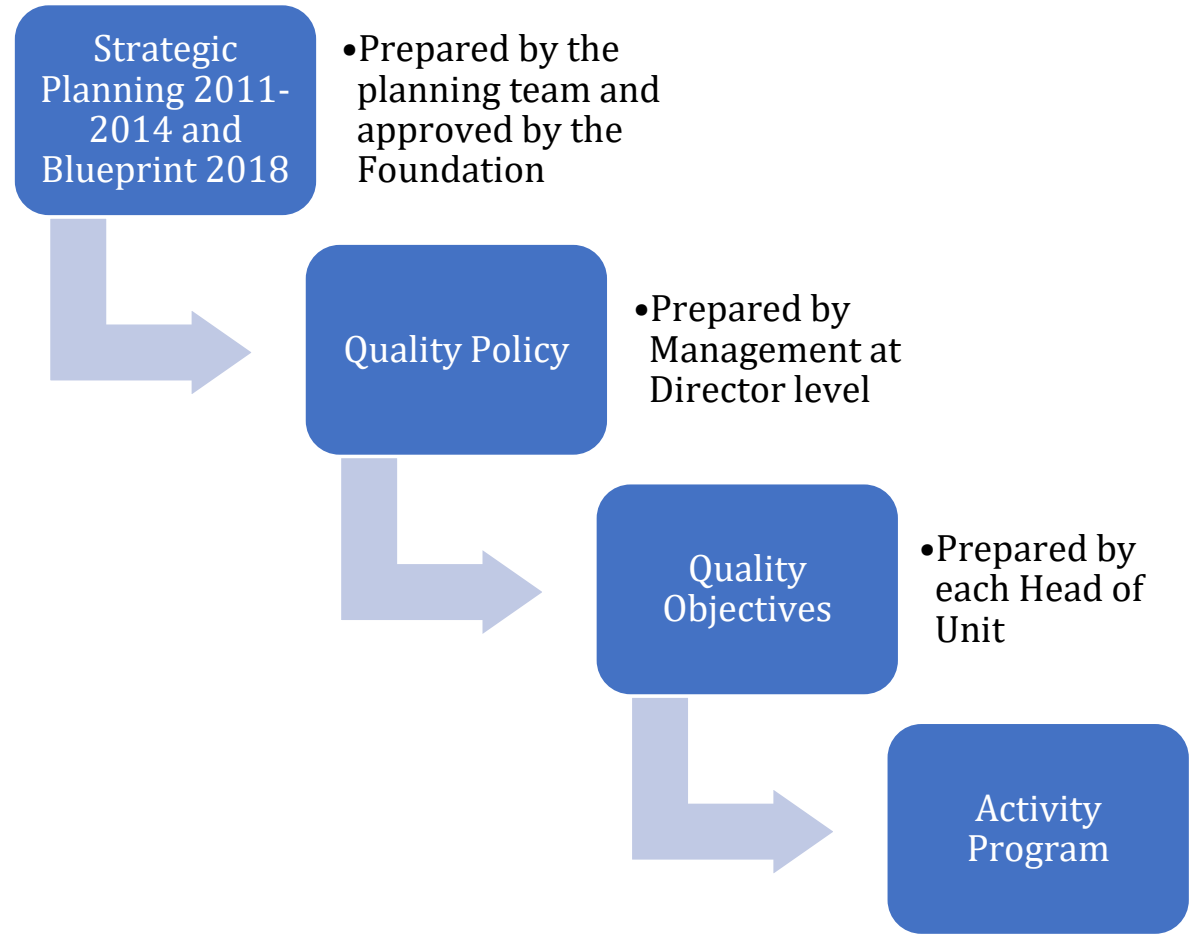

Fig. 2. Stages of implementing strategic planning for Madrasah Pembangunan

Madrasah Pembangunan uses the 2011-2014 Strategic Planning and 2018 Blueprint as an umbrella for any policies decided by management. This is because the latest strategic plans have not yet been endorsed while the old strategic plans have expired.

The two strategic plans were formulated which later became the Quality Policy, which is a policy at the Madrasah Pembangunan Director level. These quality policies are then translated by each unit under the director to be used as 
quality targets for the planning of each activity program in Madrasah Pembangunan.

The successful implementation of the quality objective programs compiled by each head of the unit will be used to measure the success of the mission and objectives set in strategic planning.

\section{Evaluation}

The assessment or evaluation process at Madrasah Pembangunan is the Madrasah Self-Evaluation (EDM) which is carried out annually to measure the position of the UIN Jakarta Madrasah Pembangunan at the national education standard level and an internal audit is carried out by the Research and Development Center for Quality Assurance (P3JM) team for Madrasah Pembangunan.

The outcomes evaluated following the eight National Education Standards are as follows:

\begin{tabular}{|c|c|c|c|}
\hline \multicolumn{2}{|r|}{ Standards } & Component & Achievements \\
\hline 1 & $\begin{array}{l}\text { Content } \\
\text { Standards }\end{array}$ & $\begin{array}{l}\text { The curriculum is } \\
\text { appropriate and } \\
\text { relevant }\end{array}$ & $\begin{array}{l}\text { The UIN Jakarta Madrasah } \\
\text { Pembangunan curriculum is } \\
\text { prepared and developed following } \\
\text { the BSNP guidelines and becomes a } \\
\text { reference for developing other } \\
\text { Madrasah curricula that have the } \\
\text { same characteristics. }\end{array}$ \\
\hline & & $\begin{array}{l}\text { Madrasas provide for } \\
\text { the personal } \\
\text { development needs of } \\
\text { students }\end{array}$ & $\begin{array}{l}\text { Madrasah Pembangunan UIN } \\
\text { Jakarta provides services and } \\
\text { guidance regularly and } \\
\text { continuously in meeting each } \\
\text { student's personal development } \\
\text { needs, both programmed and } \\
\text { based on case studies according to } \\
\text { the needs of students. }\end{array}$ \\
\hline 2 & $\begin{array}{l}\text { Process } \\
\text { Standards }\end{array}$ & $\begin{array}{l}\text { The syllabus is in } \\
\text { accordance / relevant } \\
\text { to the standard }\end{array}$ & $\begin{array}{l}\text { The syllabus at Madrasah } \\
\text { Pembangunan UIN Jakarta is } \\
\text { following SI, SKL, and KTSP } \\
\text { guidelines and has considered the } \\
\text { situation and condition of the } \\
\text { Madrasah }\end{array}$ \\
\hline & & $\mathrm{RPP}$ is designed to & RPPs are prepared by each teacher \\
\hline
\end{tabular}




\begin{tabular}{|c|c|c|c|}
\hline & & $\begin{array}{l}\text { achieve effective } \\
\text { learning and } \\
\text { according to the needs } \\
\text { of students }\end{array}$ & $\begin{array}{l}\text { for each basic competency based } \\
\text { on the principles of learning } \\
\text { planning and are reviewed } \\
\text { regularly to ensure their impact on } \\
\text { improving student learning } \\
\text { outcomes. }\end{array}$ \\
\hline & & $\begin{array}{l}\text { Learning resources } \\
\text { can be obtained easily } \\
\text { and used } \\
\text { appropriately }\end{array}$ & $\begin{array}{l}\text { UIN Jakarta Madrasah } \\
\text { Pembangunan students use their } \\
\text { own purchased (owned) learning } \\
\text { resources and various materials } \\
\text { available in the Madrasah library } \\
\text { that are easily borrowed and used } \\
\text { outside the Madrasah in a period of } \\
\text { no more than one week and can be } \\
\text { extended and can access Electronic } \\
\text { School Books ( BSE) and other } \\
\text { materials from the Madrasah e- } \\
\text { library }\end{array}$ \\
\hline & & $\begin{array}{l}\text { Learning is carried out } \\
\text { using methods that are } \\
\text { interactive, inspiring, } \\
\text { fun, creative, } \\
\text { challenging, and } \\
\text { motivating students }\end{array}$ & $\begin{array}{l}\text { The UIN Jakarta Madrasah } \\
\text { Pembangunan teachers carry out } \\
\text { interactive, inspirational, fun, and } \\
\text { challenging learning activities } \\
\text { following the RPP they have } \\
\text { compiled and are used as a } \\
\text { reference for teachers in other } \\
\text { madrasas. }\end{array}$ \\
\hline & & $\begin{array}{l}\text { Supervision and } \\
\text { Evaluation of the } \\
\text { Learning Process is } \\
\text { carried out regularly } \\
\text { and continuously }\end{array}$ & $\begin{array}{l}\text { The learning process at Madrasah } \\
\text { Pembangunan UIN Jakarta is } \\
\text { supervised and evaluated starting } \\
\text { from the planning, implementation, } \\
\text { and assessment stages of learning } \\
\text { outcomes }\end{array}$ \\
\hline 3 & $\begin{array}{l}\text { Graduate } \\
\text { competence } \\
\text { standard }\end{array}$ & $\begin{array}{l}\text { Students can achieve } \\
\text { the expected academic } \\
\text { targets }\end{array}$ & $\begin{array}{l}\text { Students show better progress } \\
\text { beyond graduation competency } \\
\text { standards, are confident and have } \\
\text { high expectations for achievement. }\end{array}$ \\
\hline & & $\begin{array}{l}\text { Students can develop } \\
\text { their full potential as } \\
\text { members of society }\end{array}$ & $\begin{array}{l}\text { Students participate actively in life } \\
\text { at the UIN Jakarta Madrasah } \\
\text { Pembangunan and in the wider } \\
\text { community. They can personally }\end{array}$ \\
\hline
\end{tabular}




\begin{tabular}{|c|c|c|c|}
\hline & & & $\begin{array}{l}\text { and socially carry out various types } \\
\text { of personal success activities in a } \\
\text { wider scope. }\end{array}$ \\
\hline \multirow[t]{3}{*}{4} & $\begin{array}{l}\text { Educators and } \\
\text { Education } \\
\text { Personnel } \\
\text { Standards }\end{array}$ & $\begin{array}{l}\text { Fulfillment of the } \\
\text { number of educators } \\
\text { and education } \\
\text { personnel is sufficient }\end{array}$ & $\begin{array}{l}\text { The number of educators at the } \\
\text { UIN Jakarta Madrasah } \\
\text { Pembangunan is very adequate to } \\
\text { provide high-quality learning } \\
\text { services for all students, including } \\
\text { students with special needs. }\end{array}$ \\
\hline & & $\begin{array}{l}\text { Qualifications of } \\
\text { educators and } \\
\text { education personnel } \\
\text { are adequate }\end{array}$ & $\begin{array}{l}\text { Madrasah Pembangunan UIN } \\
\text { Jakarta has educators with very } \\
\text { adequate qualifications from the } \\
\text { specified standards to provide a } \\
\text { high-quality learning experience } \\
\text { for all students, including special } \\
\text { needs students. }\end{array}$ \\
\hline & & $\begin{array}{l}\text { The competence of } \\
\text { educators and } \\
\text { education personnel is } \\
\text { adequate }\end{array}$ & $\begin{array}{l}\text { Madrasah Pembangunan UIN } \\
\text { Jakarta has educators with very } \\
\text { adequate competencies to provide } \\
\text { high-quality learning experiences } \\
\text { for all students, including students } \\
\text { with special needs. }\end{array}$ \\
\hline \multirow[t]{2}{*}{5} & $\begin{array}{l}\text { Standard of } \\
\text { Facilities and } \\
\text { Infrastructure }\end{array}$ & $\begin{array}{l}\text { Madrasah facilities are } \\
\text { adequate }\end{array}$ & $\begin{array}{l}\text { Madrasah Pembangunan UIN } \\
\text { Jakarta has a building whose size, } \\
\text { ventilation, and other facilities } \\
\text { exceed the SNP provisions. }\end{array}$ \\
\hline & & $\begin{array}{l}\text { The Madrasah is well } \\
\text { maintained and in } \\
\text { good condition }\end{array}$ & $\begin{array}{l}\text { Maintenance of buildings at the } \\
\text { UIN Jakarta Madrasah } \\
\text { Pembangunan is carried out } \\
\text { routinely beyond the time specified } \\
\text { in the SNP and maintenance } \\
\text { records are recorded properly. }\end{array}$ \\
\hline 6 & $\begin{array}{l}\text { Management } \\
\text { Standard }\end{array}$ & $\begin{array}{l}\text { The performance of } \\
\text { Madrasah } \\
\text { management is based } \\
\text { on teamwork and } \\
\text { strong partnerships } \\
\text { with a clear vision and } \\
\text { mission that is known } \\
\text { to all parties }\end{array}$ & $\begin{array}{l}\text { Madrasah Pembangunan UIN } \\
\text { Jakarta has a vision and mission } \\
\text { that is formulated bottom-up and } \\
\text { socialized to all stakeholders and } \\
\text { regularly reviewed according to the } \\
\text { situation, conditions, and needs of } \\
\text { the Madrasah. }\end{array}$ \\
\hline
\end{tabular}




\begin{tabular}{|c|c|c|c|}
\hline & & $\begin{array}{l}\text { The work plan has } \\
\text { clear objectives and } \\
\text { continuous } \\
\text { improvement }\end{array}$ & $\begin{array}{l}\text { Madrasah Pembangunan UIN } \\
\text { Jakarta has a work plan that is } \\
\text { formulated from the objectives } \\
\text { based on the vision and mission of } \\
\text { the Madrasah in the form of a } \\
\text { strategic plan and RKS document, } \\
\text { which is well socialized to all } \\
\text { Madrasah residents and interested } \\
\text { parties and is reviewed on an } \\
\text { ongoing basis. }\end{array}$ \\
\hline & & $\begin{array}{l}\text { Madrasah } \\
\text { Development Plans / } \\
\text { Madrasah Work Plans } \\
\text { have an impact on } \\
\text { improving learning } \\
\text { outcomes }\end{array}$ & $\begin{array}{l}\text { Madrasah Pembangunan UIN } \\
\text { Jakarta conducts self-evaluation } \\
\text { and communicates development } \\
\text { plans based on self-evaluation with } \\
\text { the education office and } \\
\text { stakeholders. }\end{array}$ \\
\hline & & $\begin{array}{l}\text { Collection and use of } \\
\text { reliable and valid data }\end{array}$ & $\begin{array}{l}\text { Madrasah Pembangunan UIN } \\
\text { Jakarta has an ICT-based data } \\
\text { management system in an effective, } \\
\text { efficient, and accountable manner } \\
\text { and is socialized to all stakeholders } \\
\text { and is connected online on the } \\
\text { Madrasah website. }\end{array}$ \\
\hline & & $\begin{array}{l}\text { Providing support and } \\
\text { professional } \\
\text { development } \\
\text { opportunities for } \\
\text { educators and } \\
\text { education personnel }\end{array}$ & $\begin{array}{l}\text { Madrasah Pembangunan UIN } \\
\text { Jakarta pays attention to every } \\
\text { educator and educational staff's } \\
\text { work results and always carries out } \\
\text { professional development in a } \\
\text { sustainable manner to improve } \\
\text { performance effectiveness. }\end{array}$ \\
\hline & & $\begin{array}{l}\text { The community takes } \\
\text { part in Madrasah life }\end{array}$ & $\begin{array}{l}\text { Residents of the UIN Jakarta } \\
\text { Madrasah Pembangunan are } \\
\text { directly involved in managing } \\
\text { academic and non-academic } \\
\text { activities as well as madrasah } \\
\text { development activities in general. }\end{array}$ \\
\hline 7 & $\begin{array}{l}\text { Financing } \\
\text { Standard }\end{array}$ & $\begin{array}{l}\text { Madrasahs plan } \\
\text { finances according to } \\
\text { standards }\end{array}$ & $\begin{array}{l}\text { The formulation of the draft budget } \\
\text { for Madrasah revenues and } \\
\text { expenditures (RAPBM) refers to } \\
\text { government regulations involving }\end{array}$ \\
\hline
\end{tabular}




\begin{tabular}{|c|c|c|c|}
\hline & & & $\begin{array}{l}\text { Madrasah committees and } \\
\text { stakeholders (foundations). }\end{array}$ \\
\hline & & $\begin{array}{l}\text { Madrasah efforts to } \\
\text { obtain additional } \\
\text { financial support }\end{array}$ & $\begin{array}{l}\text { The Madrasah Pembangunan UIN } \\
\text { Jakarta creatively explores various } \\
\text { sources to get additional income. }\end{array}$ \\
\hline & & $\begin{array}{l}\text { Madrasahs ensure } \\
\text { equal access }\end{array}$ & $\begin{array}{l}\text { The UIN Jakarta Madrasah } \\
\text { Pembangunan serves students } \\
\text { from various socioeconomic levels, } \\
\text { including students with special } \\
\text { needs and promotes equal access } \\
\text { for all students. }\end{array}$ \\
\hline 8 & $\begin{array}{l}\text { Assessment } \\
\text { Standards }\end{array}$ & $\begin{array}{l}\text { The assessment } \\
\text { system is structured to } \\
\text { assess students both } \\
\text { in the academic and } \\
\text { non-academic fields }\end{array}$ & $\begin{array}{l}\text { The teachers of the UIN Jakarta } \\
\text { Madrasah Pembangunan formulate } \\
\text { an assessment plan for the learning } \\
\text { outcomes of students towards the } \\
\text { expected competency achievement } \\
\text { and are informed to students so } \\
\text { that each student understands the } \\
\text { competency targets that must be } \\
\text { achieved. }\end{array}$ \\
\hline & & $\begin{array}{l}\text { The assessment has an } \\
\text { impact on the learning } \\
\text { process }\end{array}$ & $\begin{array}{l}\text { All Madrasah Pembangunan UIN } \\
\text { Jakarta teachers routinely record } \\
\text { each student's progress, give } \\
\text { comments and input, and inform } \\
\text { students individually and } \\
\text { periodically. }\end{array}$ \\
\hline & & $\begin{array}{l}\text { Parents of students } \\
\text { are involved in their } \\
\text { child's learning } \\
\text { process }\end{array}$ & $\begin{array}{l}\text { The UIN Jakarta Madrasah } \\
\text { Pembangunan makes regular } \\
\text { reports to parents regarding the } \\
\text { achievement of student learning } \\
\text { outcomes and offers the } \\
\text { opportunity to discuss their child's } \\
\text { progress and submit suggestions } \\
\text { for improving student learning } \\
\text { outcomes. }\end{array}$ \\
\hline
\end{tabular}




\section{Volume 4 Number 1 Sept 2020}

\section{CONCLUSION}

Strategic planning has been implemented well and has become a quality assurance system as outlined in each unit's quality policy and quality objectives in the Madrasah Pembangunan as a reference for every policy in management. The 2018 Madrasah Pembangunan Blueprint is a planning document with a vision that is in line with current trends and can be applied to accommodate developments in the world of education that lead to technological advances and global information flows. This is also related to the need for educational methods during the Covid-19 pandemic. The 2018 Madrasah Pembangunan Blueprint has not been formalized as a reference document for the Madrasah Pembangunan. Effective strategic planning requires a great commitment from the officeholders and their executors so that the effort and time that has been sacrificed in the formulation process does not go to waste.

\section{REFERENCES}

Allison, M., \& Kaye, J. (2015). Strategic Planning for Nonprofit Organizations. New Jersey: John Willey \& Son, Inc.

Bell, L. (2004). Strategic Planning in Primary Schools: A Tale of No Significances? Management in Education, 33-36.

Bryson, J. M. (2011). Strategic Planning for Public and Nonprofit Organizations. San Francisco: John Wiley \& Sons, Inc.

Bryson, J. M., Crosby, B. C., \& Bryson, J. K. (2009). Understanding Strategic Planning and The Formulation and Implementation of Strategic Plans as A Way of Knowing: The Contributions of Actor-Network Theory. International Public Management Journal, 172-207.

Dr. Burhan, N. (1994). Manajemen Strategik. Jakarta: PT. Pustaka Binaman Pressindo.

Fatah, N. (2013). Landasan Manajemen Pendidikan. Bandung: PT. Remaja Rosdakarya.

Hinton, E. K. (2012). A Practical Guide to Strategic Planning in Higher Education. Brookdale: Society for College and University Planning.

Hu, J., Liu, H., Chen, Y., \& Qin, J. (2017). Strategic Planning and The Stratification of Chinese Higher Education Institutions. International Journal of Educational Development.

Madrasah Pembangunan Ciputat, T. (2014). Blue Print Madrasah Pembangunan. Tangerang Selatan, Banten.

Maleka, S. (2014). Strategy Management and Strategic Planning Process. DTPS Strategic Planning \& Monitoring At: Pretoria Volume: 1 (P. 30). South Africa: Research Gate.

Montana, P., \& Charnov, B. (2008). Management. New York, Hauppauge. 
Nolan, T. M., Goodstein, L. D., \& Goostein, J. (2008). Applied Strategic Planning. An Introduction. San Fransisco: Pfeiffer A Willey Imprint.

Olsen, E. (2012). Strategic Planning Kit for Dummies. New Jersey: John Willey \& Son, Inc.

Olsen, J. B. (1982). The Game Plan: Governance with Foresight. Washington, DC: Council of State Planning Agencies.

Salusu, J. (1996). Pengambilan Keputusan Strategik Untuk Organisasi Publik Dan Organisasi Nonprofit. Jakarta: PT. Grasindo.

Schlebusch, G., \& Mokhatle, M. (2016). Strategic Planning as A Management Tool for School Principals in Rural Schools in The Motheo District. International Journal Education Science, 342-348.

Sheridan, D. H. (1998). An Analysis of Strategic Planning Practices at Ontario Colleges of Applied Arts and Technology. Ottawa: National Library of Canada.

Stainer, G. A. (1997). The Step by Step Strategic Planning. New York: Free Press Paperbacks.

Sugiyono. (2015). Metode Penelitian Pendidikan: Pendekatan Kuantitatif, Kualitatif Dan R\&D. Bandung: Alfabeta.

Sukmadinata, N. S. (2011). Metode Penelitian Pendidikan. Bandung: PT. Remaja Rosdakarya.

Tilaar, H. (2000). Paradigma Baru Pendidikan Nasional. Jakarta: Rineka Cipta.

Wyk, C. V., \& Moeng, B. G. (2014). The Design and Implementation of a Strategic Plan in Primary Schools. International Business \& Economics Research Journal, 137-143. 